\title{
Estimation of genetic parameters for daily milk yields of primiparous Iranian Holstein cows
}

\author{
Khabat Kheirabadi', Sadegh Alijani', Ludmila Zavadilová2, Seyed Abbas Rafat ${ }^{1}$ and \\ Gholamali Moghaddam
}

'Department of Animal Science, University of Tabriz, Tabriz, Iran, ${ }^{2}$ Institute of Animal Science, Prague-Uhříněves, Czech Republic

\begin{abstract}
Applying a multiple trait random regression (MT-RR) in national level and for whole test day records of a country is a great advance in animal breeding context. Having reliable (co) variance components is a critical step in applying multiple traits genetic evaluation especially in developing countries. Genetic parameters of milk, fat and protein yields were estimated for Iranian Holstein dairy cows. Data included 276692 test day (TD) production traits records collected of 30705 primiparous cows belonging to 619 sires. An animal multi-trait random regression model was employed in the analyses using the restricted maximum likelihood (REML) method. The model included herd-test-date, age-season of calving (by applying a fixed regression for each subclass of this effect) and year of calving as fixed effects and random regression (RR) coefficients for additive genetic (AG) and permanent environmental (PE) effects. Obtained results showed that daily heritabilities ranged from 0.10 to 0.21 for milk, from 0.05 to 0.08 for fat and from 0.08 to 0.18 for protein yield. Estimated heritability for $305-\mathrm{d}$ milk, fat and protein yields were $0.25,0.20$ and 0.25 , respectively. Correlations between individual test day records within traits were high for adjacent tests (nearly 1) and decreased as the interval between tests increased. Correlations between yields of milk, fat and protein on a given test day are also high and greater during late lactation than during early or mid-lactation. Genetic correlations between 305-d yield traits ranged from 0.75 to 0.92. The largest genetic correlation, as well as permanent environmental correlation, was observed between milk and protein yield.
\end{abstract}

Keywords: test day yield, multiple traits, genetic parameter

Archiv Tierzucht 56 (2013) 44, 455-466

doi: 10.7482/0003-9438-56-044

Corresponding author:

Sadegh Alijani; email: sad-ali@tabrizu.ac.ir

Department of Animal Science, University of Tabriz, 29th Bahman Bolvard East Azarbaiejan Tabriz, Iran

() 2013 by the authors; licensee Leibniz Institute for Farm Animal Biology (FBN), Dummerstorf, Germany. This is an Open Access article distributed under the terms and conditions of the Creative Commons Attribution 3.0 License (http://creativecommons.org/licenses/by/3.0/).
Received: 9 October 2012

Accepted: 31 January 2013

Online: 27 March 2013 
Abbreviations: AG: additive genetic, DIM: days in milk, HTD: herd-test date, MT: multiple traits, PE: permanent environmental, REML: restricted maximum likelihood, RR: random regression, SD: standard deviation, TD: test day

\section{Introduction}

The production level of yield traits is one of the most important factors that influence the economic efficiency of dairy farms. The production level of a dairy cow is determined by a joint effect of genetic and environmental factors. The estimation of (co)variance components is vital for the development of genetic evaluation systems based on test day (TD) yields. The use of an appropriate method for genetic evaluation of dairy animals is an important aspect of dairy cattle production. Various TD models have been proposed for use in the genetic evaluation of dairy cattle. The use of the random regression (RR) model makes it possible to study changes in TD records over time and to get a better understanding of lactation genetics (Swalve \& Guo 1999). Therefore, at present the RR-TD model is referred to be the most precise model for the estimation of production traits in dairy cattle. Applying a multiple traits (MT) RR in national level for whole TD records of a country is a great advance in animal breeding context. The MT analysis increases accuracy of estimated breeding values of less frequently measured traits. Hence, a multiple trait RR-TD model should reduce biases in genetic evaluations and increase accuracy (Lidauer \& Mäntysaari 1999). Improved accuracy is especially important in developing countries, where data are scarce and costly.

In the RR model for describing the lactation curve, different functions have been used in the fixed and random part of random regression models. The function can be either linear or non-linear. Generally, the Legendre polynomials have largely been used to fit random curves due to their ability of describing the variation along the period (Bignardi et al. 2009). Some evidence has been found in favour of a lower degree needed for the genetic than for the permanent environmental components (Van Der Werf et al. 1998, Pool et al. 2000, LópezRomero \& Carabaño 2003).

Although some investigations have been carried out in Iranian Holstein dairy cows in regard to the estimation of genetic parameters of milk yield traits by MT animal model (YousefiGolverdi et al. 2012) and MT-RR animal model (Kheirabdi et al. 2012), genetic and permanent environmental correlations for different milk yield traits in different and selected days in milk (DIM) have not yet been evaluated (according to the authors' knowledge). Therefore, the objective of the present study was to estimate (co)variance components of milk, fat and protein yields in the first lactation of Iranian Holstein cows with a MT-RR animal model by using the restricted maximum likelihood (REML) method. Another goal was to estimate the genetic and permanent environmental correlations between production traits in different and selected DIM.

\section{Material and methods}

Data

Data on daily records of primiparous Iranian Holstein dairy cows with calving in 79 different herds were obtained from the animal breeding centre of Iran. This data set consisted of TD records on milk, fat and protein yield. The year of calving was required to be between 2005 
and 2010. Records obtained before 5 or after 305 DIM were discarded. Cows were removed if they had their first DIM after $d 60$. Correlations of yields on consecutive TD are affected by the interval between tests (Schaeffer \& Burnside 1976), thus in any interval between consecutive TD records that was less than 15 days the second one was removed. All records belonging to the cows whose sire had less than 10 daughters and their herds comprised less than 150 cows were removed. A minimum of 8 TD records for milk, fat and protein yield was required for a cow observation to be included in the analysis. Further edits excluded irregular data for daily milk yield $(<2.0$ and $>48 \mathrm{~kg})$, fat content $(<1.5 \%$ and $>9 \%)$ and protein percentage $(<1 \%$ and $>7 \%$ ). Edited data included 276692 TD records collected on 30705 first lactation cows that were daughters of 619 sires. The age of calving was restricted from 23 to 35 months. Four seasons (spring, summer, fall and winter) and 3 subclasses for age at calving $(<26,26$ to 30 and $>30$ months) were defined. Pedigree information was obtained from the national database. The animals that had not contributing connections (i.e. both or one of the parents unknown) were excluded. A summary of the data is given in Table 1.

Table 1

Description of used test day data set to estimate (co)variance components

Item

Test day records used in the analysis

Mean of milk yield (SD)

Mean of fat yield (SD)

Mean of protein yield (SD)

Cows with record used in the analysis

Number of herds

Number of sires

Average number of daughters pre bull

Average number of test day records per cow

Average number of test day records per HTD classes

Number of animals in pedigree file used in the analysis
276692

$31.5(6.70)$

$1.06(0.31)$

$0.96(0.22)$

30705

79

619

49.6

9

58.3

1097460

Model

Model specification and the choice of fixed effects to be considered in the model were based on checking their significance with Proc GLM of SAS 9.1.3 software (SAS Institute Inc., Cary, NC, USA) and the variables which were significant at $P<0.05$ level were included in the model.

Data were analysed with a 3-trait RR-TD animal model by the REML method using the REMLF90 software (Misztal et al. 2002). Convergence criterion used was $10^{-8}$. In this research, the orders of two (quadratic) and three (cubic) of Legendre polynomial (Kirkpatrick et al. 1990) were used for additive genetic (AG) and permanent environmental (PE) effects, respectively. Homogeneous residual variance was assumed throughout lactation. The model was as follows:

$$
y_{i j k l m}=Y C_{i}+H T D_{j}+\sum_{n=0}^{2} \beta_{k n} Z_{m n}+\sum_{n=0}^{2} a_{l n} Z_{m n}+\sum_{n=0}^{3} p e_{l n} Z_{m n}+e_{i j k l m}
$$

where $y_{i j k l m}$ is the observation of TD record $m$ of cow / obtained at age-season of calving $k$ within herd-test day effect $j$ of a cow calved at the year of calving $i ; Y C_{i}$ is the fixed effect 
of year of calving $(i=1 \ldots, 6) ; H T D_{j}$ is the fixed effect of Herd-Test-Date $(j=1 \ldots, 4747) ; \beta_{k n}$ are the fixed regression coefficients specific to subclass $k$ of age-season of calving $(k=1 \ldots, 12)$; $Z_{m n}$ is the intercept and covariates associated with DIM; $a_{i n}$ is the additive genetic random regression coefficients specific to cow $l ; p e_{l n}$ is the permanent environmental random regression coefficients specific to cow $l ; e_{i j k m}$ is the random residual corresponding to $y_{i j k l m}$.

\section{Functions of Parameters}

Heritability for day $i\left(h_{i}^{2}\right)$ in the lactation, heritability for 305-d production $\left(h_{(305 \mathrm{~d})}^{2}\right)$, genetic correlation $\left(r_{g(i, j)}\right)$ between trait $f$ and trait $p$ and genetic correlations $\left(r_{g(305)}\right)$ among 305-d traits were calculated, respectively, as described elsewhere (Jakobsen et al. 2002):

$$
\begin{aligned}
& h_{i}^{2}=\frac{\sigma_{a(i)}^{2}}{\sigma_{a(i)}^{2}+\sigma_{p e(i)}^{2}+\sigma_{e}^{2}} \\
& h_{(305 d)}^{2}=\frac{\sigma_{a(305)}^{2}}{\sigma_{a(305)}^{2}+\sigma_{p e(305)}^{2}+301 \times \sigma_{e}^{2}} \\
& r_{g(i, j)}=\frac{\delta_{f p(i, j)}}{\sigma_{f f(i, j)} \times \sigma_{p p(i, j)}} \\
& r_{g(305 d)}=\frac{\delta_{f p(305)}}{\sigma_{f f(350)} \times \sigma_{p p(305)}}
\end{aligned}
$$

where $\sigma_{a(i)}^{2}$ and $\sigma_{p(i)}^{2}$ are AG and PE variances for day $i ; \sigma_{a(305)}^{2}$ and $\sigma_{p e(30)}^{2}$ are AG and PE variances for 305-d production; $\delta_{f p(i, j)}$ are covariances between traits $f$ and $p, \sigma_{f f(i, j)}$ and $\sigma_{p p(i, j)}$ are standard deviations of any trait. Note that $i=j$ if observations were on the same day and $i \neq j$ if observations were on different days.

Let $M a$ and $M p e$ indicate as matrices of AG and PE (co)variances of regression coefficients and $a i$ orders of function; $Z t$ and $Z_{305}$ as a matrix (DIM*ai) of function coefficients evaluated at day $t$ and vector $\left(1^{*} a i\right)$ of the summations of function corresponding to total lactation; Ka as a matrix of AG (co)variance between traits $f$ and $p$, respectively. Then the following formulas were used for estimation of genetic parameters:

$$
\begin{aligned}
& \sigma_{a(i)}^{2}=Z_{t} \times M a \times Z_{t}^{\prime} \\
& \sigma_{p e(i)}^{2}=Z_{t} \times M p e \times Z_{t}^{\prime} \\
& \sigma_{a(305)}^{2}=Z_{305} \times M a \times Z_{305}^{\prime} \\
& \sigma_{p e(305)}^{2}=Z_{305} \times M p e \times Z_{305}^{\prime} \\
& \delta_{f p(i, j)}=Z_{t} \times K a \times Z_{t}^{\prime} \\
& \delta_{f p(305)}=Z_{305} \times K a \times Z_{305}^{\prime}
\end{aligned}
$$




\section{Results and discussion}

\section{Heritabilities and variances}

Having reliable (co)variance components is a critical step in applying multiple trait genetic evaluation especially in the developing countries. Estimates of AG and PE (co)variances of RR coefficients are presented in Table 2.

In the present study, the patterns of variance components across the lactation for milk yields are shown in Figure 1. For milk and protein yield the genetic variances were moderate at the beginning, small in the middle and large at the end of lactation. For fat yield this trend decreased from DIM 5 to DIM 110 and subsequently increased steadily during lactation period. As expected, the PE variance estimates were consistently larger than AG estimates for all traits. For all traits studied, PE variances initially decreased at the beginning of lactation (5-60 DIM), remained constant in the central period and tended to increase at the end (after 255 DIM). Decreasing permanent environmental variance during lactation suggests that PE factor had the low influence on test day milk yields during 305-d milk production except at the edge of lactation. In general, the trends in the AG and PE variance estimates throughout lactation obtained in this study are comparable to trends found by López-Romero and Carabaño (2003). On the contrary to the results achieved in this study, AG variances show a decreasing pattern towards the end of lactation for Dutch and Turkish Holstein Friesian (Pool et al. 2000, Takma \& Akbas 2007).

Table 2

Estimated genetic and permanent environmental variances (diagonal) and covariances (below diagonal) for random regression coefficients ${ }^{1}$

\begin{tabular}{lcccccrrrr}
\hline & & \multicolumn{3}{c}{ Additive genetic coefficients } & \multicolumn{5}{c}{ Permanent environmental coefficients } \\
& & $\mathrm{a}_{0}$ & $\mathrm{a}_{1}$ & $\mathrm{a}_{2}$ & & $\mathrm{p}_{0}$ & $\mathrm{p}_{1}$ & \multicolumn{1}{c}{$\mathrm{p}_{2}$} & $\mathrm{p}_{3}$ \\
\hline Milk & $\mathrm{a}_{0}$ & 9.598 & & & $\mathrm{p}_{0}$ & 25.630 & & & \\
& $\mathrm{a}_{1}$ & 1.825 & 1.352 & & $\mathrm{p}_{1}$ & 1.284 & 4.639 & & \\
& $\mathrm{a}_{2}$ & -0.516 & -0.279 & 0.421 & $\mathrm{p}_{2}$ & -0.604 & -0.371 & 1.957 & \\
& & & & & $\mathrm{p}_{3}$ & 0.538 & 0.0251 & -0.774 & 2.132 \\
\multirow{4}{*}{ Fat } & $\mathrm{a}_{0}$ & 0.796 & & & $\mathrm{p}_{0}$ & 2.704 & & & \\
& $\mathrm{a}_{1}$ & 0.117 & 0.147 & & $\mathrm{p}_{1}$ & -0.036 & 0.535 & & \\
& $\mathrm{a}_{2}$ & 0.029 & -0.034 & 0.086 & $\mathrm{p}_{2}$ & -0.033 & -0.136 & 0.291 & \\
& & & & & $\mathrm{p}_{3}$ & -0.025 & 0.019 & -0.142 & 0.194 \\
\multirow{5}{*}{ Protein } & $\mathrm{a}_{0}$ & 0.787 & & & $\mathrm{p}_{0}$ & 1.969 & & & \\
& $\mathrm{a}_{1}$ & 0.190 & 0.130 & & $\mathrm{p}_{1}$ & 0.1459 & 0.411 & & \\
& $\mathrm{a}_{2}$ & -0.024 & -0.011 & 0.036 & $\mathrm{p}_{2}$ & -0.038 & -0.025 & 0.180 & \\
& & & & & $\mathrm{p}_{3}$ & 0.004 & -0.011 & -0.059 & 0.131 \\
\hline
\end{tabular}

$a_{i}$ : random regression coefficient of additive genetic effect to $i$-th Legendre polynomials, $p_{i}$ : random regression coefficient of permanent environmental effect to i-th Legendre polynomials, ${ }^{\prime}(\mathrm{Co})$ variances for fat and protein yield are multiplied by $10^{2}$.

Clearly the estimations of heritability of test day records were not constant throughout the lactation. Heritability estimates along the lactation trajectory (Figure 2) showed shapes similar to the genetic variation but were less extreme at the beginning of the trajectory because of higher PE variances. In general, heritability for milk yield was low at the peak of lactation, rose toward the middle of the second part of lactation and then was fairly stable 
throughout the remainder of lactation. The maximum heritability for milk yield was close to 0.21 and was founded around 270 to 305 DIM. The minimum (0.10) was at the beginning of the lactation. In an earlier analysis of individual TD milk yield as separate traits in a univariate analysis (Shadparvar \& Yazdanshenas 2005), heritabilities varied from 0.11 to 0.16 in the first four tests but ranged from 0.17 to 0.19 for the remaining part of the lactation. The trend of daily heritabilities for milk yield in this study was also similar to the results obtained with a TD model (Abdullahpour et al. 2010) on the same population used for this study. Moreover, the patterns of milk and protein yield heritability curves of the current study were comparable with those obtained by Muir et al. (2007) on Italian data. However, some authors estimated the highest heritability at both extremes of the lactation curve (Jamrozik \& Schaeffer 1997, Samoré et al. 2002) and other authors found the highest heritabilities in the middle of lactation (Rekaya et al. 1999, Jensen 2001, Jakobsen et al. 2002, Druet et al. 2003, De Roos et al. 2004, Zavadilová et al. 2005, Takma \& Akbas 2007, Hammami et al. 2008). For fat yield, heritability slightly decreased from the onset of lactation, attaining minimum at 110 DIM and increasing thereafter. The shape of daily heritability for protein yield was similar to that for milk yield with the minimum at the peak of lactation; then they increased toward the end of lactation. The increase in daily heritability estimates with stage of lactation observed in the study was due to the increasing trend in AG variances, especially for milk and protein yield, and decreases in PE variance. This means that the effect of environmental variance during DIM is considerable and it should not be assumed fixed during lactation.
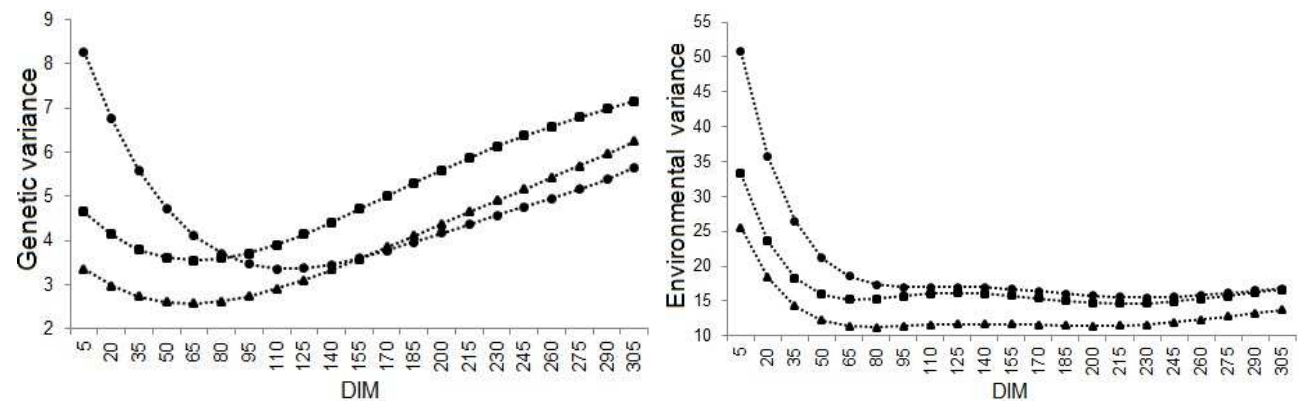

*Variances for fat and protein yield are multiplied by 103.

Figure 1

Additive genetic and permanent environmental variances* estimates of test day milk (squares), fat (circles) and protein (triangles) yields

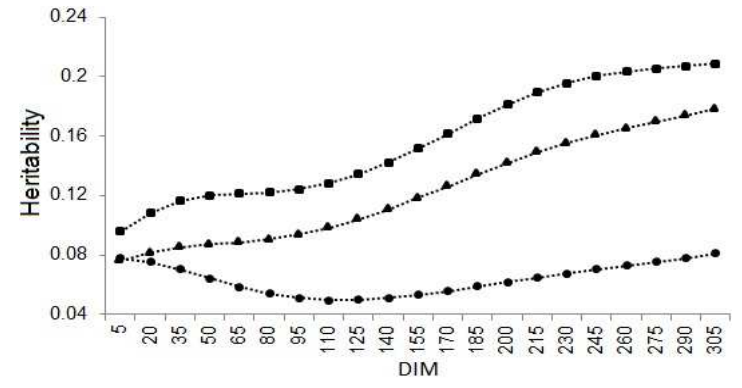

Figure 2

Heritability for milk (squares), fat (circles) and protein (triangles) yield as a function of DIM 
The largest daily heritabilities were obtained for milk yield (0.10-0.21) while the lowest heritabilities were found for fat yield (0.05-0.08). This was in agreement with most other studies (Tijani et al. 1999, Lidauer et al. 2003, Strabel et al. 2004, Zavadilová et al. 2005, Muir et al. 2007, Hammami et al. 2008). However, De Roos et al. (2004) reported the smallest heritabilities for protein yield in the first lactation.

Heritabilities for $305-\mathrm{d}$ milk yields ( 0.25 for milk, 0.20 for fat yield and 0.25 for protein yield) were similar to the results obtained with a 305-d multivariate model (Sahebhonar et al. 2010) on the same population used for this study. In all cases the heritability for TD records was lower than the corresponding complete lactation. Similar findings were reported in previous studies on other data (Swalve 1995, Lidauer \& Mäntysaari 1999, De Roos et al. 2001, Samoré et al. 2002, Hammami et al. 2008). Those authors reported heritability for TD records was lower than the corresponding complete lactation. However, Jamrozik \& Schaeffer (1997), Strabel et al. (2004) and Zavadilová et al. (2005) obtained larger values of daily heritabilities than those for 305- $d$ yield. Obtained heritabilities of the 305- $d$ were comparable with $0.30,0.27$ and 0.28 reported by Muir et al. (2007) on Italian Holsteins using multiple-trait multiple-lactation RR test day model. However, heritabilities of yield traits for the Iranian Holsteins were smaller than those obtained in other data (De Roos et al. 2001, De Roos et al. 2004). Strabel \& Jamrozik (2006) and Hammami et al. (2008) reported the same results for first lactation, which were smaller than the values obtained in the current research. There are several factors that might influence the level of heritability estimates. Among the many reasons which cause the differences in heritability estimates are different models and different used functions (as well as different orders) and different levels of yield. In earlier works on Tunisian Holstein, RR models were used for estimation of genetic parameters for a population with low production levels (Hammami et al. 2008). De Veer \& Van Vleck (1987) split production records from United State cows into three levels on the basis of mean milk yield of the herds. They showed that heritabilities increased as production level increased.

\section{Genetic and PE correlations}

Within traits: Genetic $\left(r_{g}\right)$ and permanent environmental $\left(r_{p e}\right)$ correlations between test day milk yields, test day fat yields and test day protein yields at different stages of lactation are shown in Figure 3. Our results are close to those obtained by Lidauer et al. (2003). For all traits the highest $r_{g}$ of close to unity was observed between tests close to each other and the lowest was observed between the initial (DIM 5) and final (DIM 270 to 305) stages of lactation. As could be seen (Figure 3), genetic correlations among tests in different stages are positive and higher than 0.3 and suggest that selection for increasing milk yield in each part of lactation has a positive effect on milk yield in the other parts lactation. These graphs indicate that $r_{g}$ between individual test days are more alike for milk and protein yield than for fat yield. However, $r_{g}$ coefficients were slightly higher within the protein yield in comparison to other traits, even when DIM were far apart. For instance, the $r_{g}$ between days 5 and 305 was 0.37 for protein yield in comparison with 0.35 and 0.30 for milk and fat yield, respectively.

The $r_{p e}$ coefficients were similar to the $r_{g}$ of the same trait; the highest was between adjacent DIM (nearly 1) and decreased as DIM got further apart. The environmental correlations were slightly lower than the corresponding $r_{g}$. The correlation between PE effects decreased much faster than AG effects as test day became more apart (see Figure 3). However, the $r_{p e}$ 
coefficients between the initial and final DIM $(0.43,0.40$ and 0.40 for milk, fat and protein yields) were higher than those estimated for corresponding genetic correlations.

Among traits: As in the case of $r_{g}$ within traits, $r_{g}$ between traits tended to decrease as DIM got further apart (see Figure 4). Therefore, the highest $r_{g}$ between production traits was observed between adjacent DIM, usually about 0.65 to 0.92 . The genetic correlations were particularly higher between milk and protein yield, even when DIM were far apart. For instance, the $r_{g}$ between days 25 and 305 was 0.53 between milk and protein yields compared with 0.22 and 0.48 between milk-fat and fat-protein yields, respectively. Ranges of this trend were similar to those estimated in U.S Holsteins (Tijani et al. 1999) and estimated in Finnish Ayrshire, Holstein Friesian and Finnish cattle (Lidauer et al. 2003). Based on obtained results, the $r_{p e}$ coefficients between traits were higher than corresponding genetic correlation and this is due to the fact that environmental effects among traits were more correlated than AG effects.
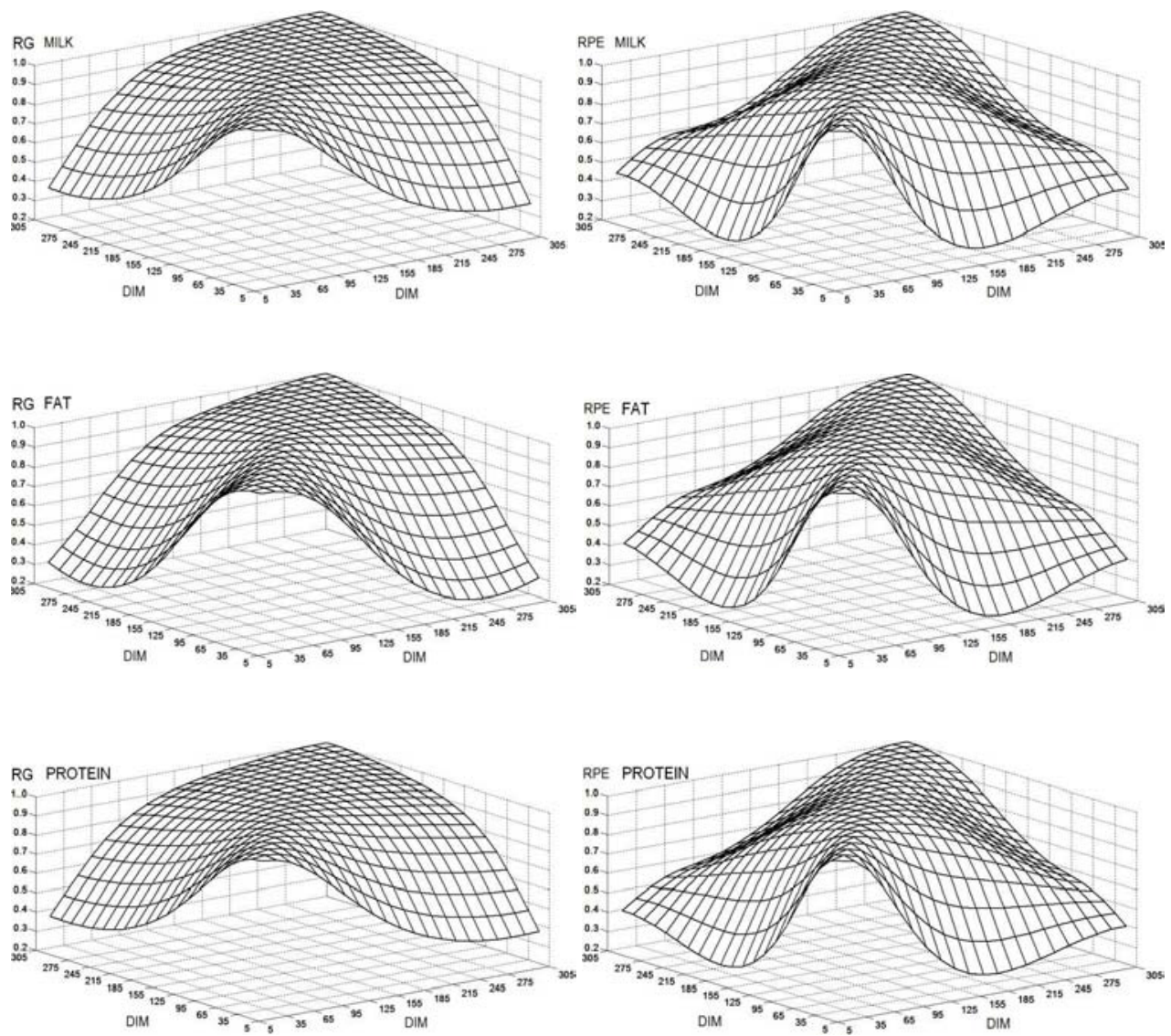

Figure 3

Genetic $\left(r_{g}\right)$ and permanent environmental $\left(r_{p e}\right)$ correlations between test day milk, fat and protein yields at different stages of lactation for the same trait 

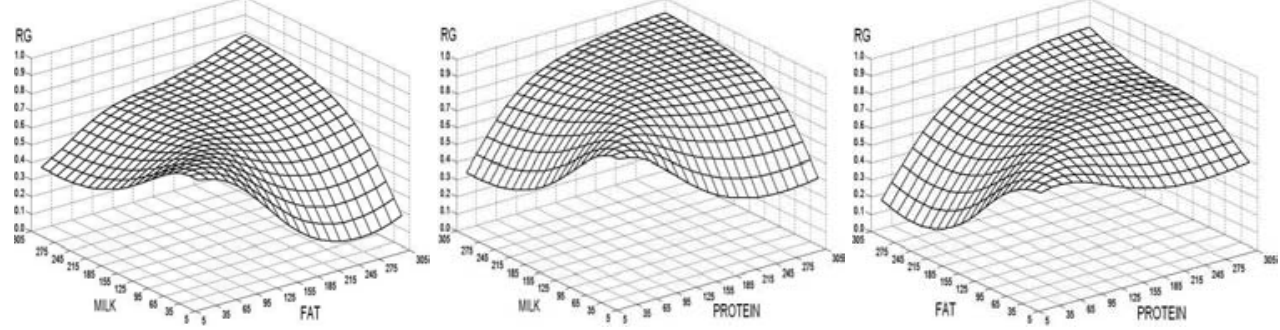

Figure 4

Genetic correlations $\left(r_{g}\right)$ between test-day production of milk and fat, milk and protein and fat and protein yields

As a consequence, genetic correlations among yields in different stages are positive and higher than 0.1 (see Figures 4, and 5) and suggest that selection for increased milk yield in each part of lactation have a positive effect on milk yields in the other parts of lactation.

Figure 5 presents the $r_{g}$ and $r_{p e}$ between test day milk yields at the same DIM. The correlations between adjacent DIM tended to increase with DIM except for the initial stages of lactation between the milk and fat yield. The genetic and environmental correlations between milk and protein yields tended to be more stable over the same DIM. Days in milk 20 at the beginning, DIM 140 in the middle and DIM 260 at the end of lactation were chosen to represent the environmental correlation structure of test day yields and results are shown in Figure 6. The closer test days were to 20, 140 and $260 \mathrm{~d}$ the higher permanent environmental correlation were shown in this Figure. Permanent environmental correlation between two ends of lactation were highest between milk and protein yields. For instance, between DIM 20 milk and 305 protein or between DIM 260 milk and 5 protein is about 0.46 or 0.37 in comparison with 0.44 and 0.32 between DIM 20 milk and 305 fat and between DIM 260 milk and 5 fat, respectively. This agrees with other investigations. This figure also shows that environmental correlations were greater during the end of lactation than during mid or late lactation.
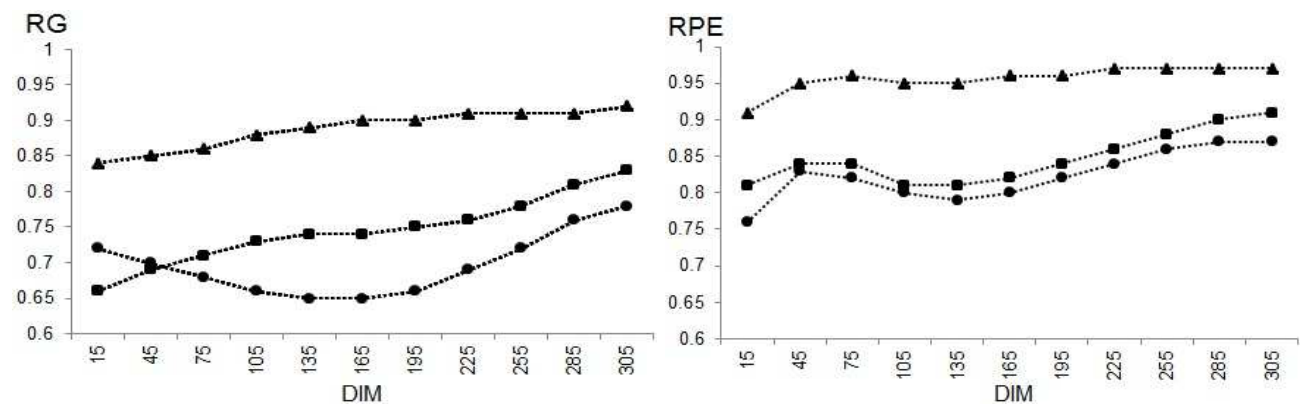

Figure 5

Genetic and permanent environmental (PE) correlations for milk and fat (circle), milk and protein (triangular) and fat and protein yield (square) 

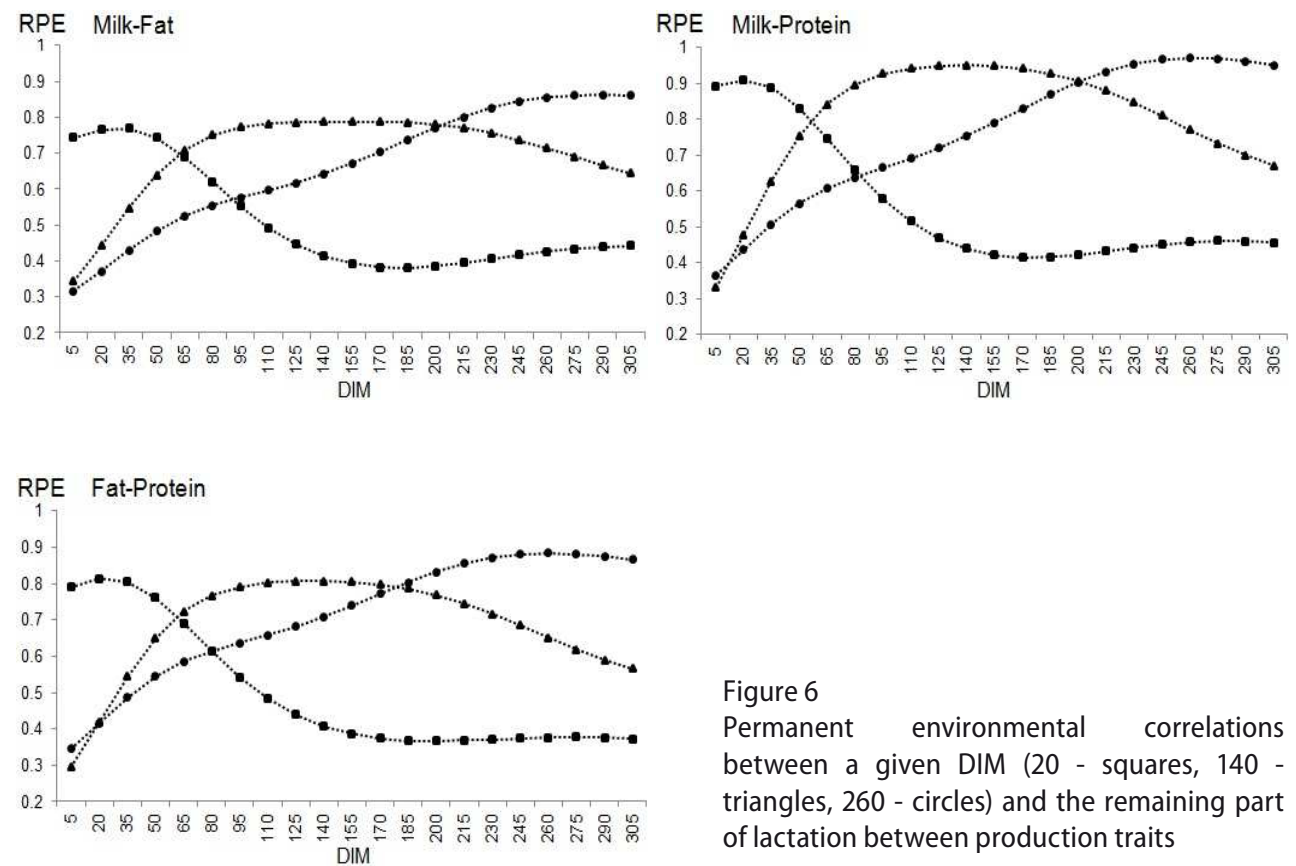

Figure 6

Permanent environmental correlations between a given DIM (20 - squares, 140 triangles, 260 - circles) and the remaining part of lactation between production traits

The estimates of AG and PE covariances and corresponding correlations of 305-d yields between production traits are presented in Table 5 . The PE covariances between any two traits were higher than the corresponding genetic covariances. The $r_{g}$ and $r_{p e}$ for 305-d yields between production traits were relatively high $(>0.80)$ except for the $r_{g}$ between milk and fat yield, which was below 0.80 . Estimated values of $r_{g}$ coefficients between production traits for the same lactation were significantly higher than estimates in Italian Holsteins (Samoré et al. 2002, Muir et al. 2007) but were similar to those estimated in Canadian Holsteins (Jamrozik \& Schaeffer 2003) and Czech Holsteins (Zavadilová et al. 2005). However, they were lower than that obtained in Tunisian Holsteins using a multi-trait multi-lactation TD model (Hammami et al. 2008). As in case of $r_{g^{\prime}}$ environmental correlations were higher for milk and protein yield and lower for milk and fat yield. As a consequence, the $r_{p e}$ between any two traits were higher than the respective $r_{g}$. This indicated that the PE effect needed to be modeled with more, higher orders of fit than necessary for the genetic component.

Table 5

Estimates of covariances and correlations between production traits for 305-day milk yield

\begin{tabular}{lccr}
\hline Genetic parameters & Milk-Fat & Milk-Protein & Fat-Protein \\
\hline AG covariance & 18791 & 22859 & 593 \\
PE covariance & 65278 & 62497 & 1842 \\
AG correlation & 0.75 & 0.92 & 0.83 \\
PE correlation & 0.87 & 0.97 & 0.88 \\
\hline
\end{tabular}


Genetic parameters were estimated by a MT-RR animal model with Legendre polynomials in Iranian Holsteins. Estimates of (co)variances components obtained in this study for the Iranian Holstein will be used as parameters for MT-RR models that will be soon adopted for genetic evaluation of production traits in Iran. For all traits, heritability estimates increased as lactation progressed and were highest in the second half of lactation. Based on the results of this study, daily heritability estimates of fat yield were small and did not even exceed 0.08 throughout lactation. Pricing system and also feeding system in Iran could be a justification of the opposite shapes of fat heritability when compared with other production traits. On the other hand, heritabilities as well as AG and PE correlations among daily milk yields tended to be increased at the end of lactation that was clear between DIM 225 and 305. However, the magnitude and trend of the heritabilities and correlations may suggest that improvement in milk yield production of Iranian Holsteins could be achieved by basing selection on the yield potential of animals in the end of lactation.

\section{References}

Abdullahpour R, Moradi Shahrbabak M, Nejati-Javaremi A, Vaez Torshizi R (2010) Genetic Analysis of Daily Milk, Fat Percentage and Protein Percentage of Iranian First Lactation Holstein Cattle. World Appl Sci 10, 1042-1046

Bignardi AB, El Faro L, Cardoso VL, Machado PF, de Albuquerque LG (2009) Random regression models to estimate test-day milk yield genetic parameters Holstein cows in Southeastern Brazil. Livest Sci 123, 1-7

De Roos APW, Harbers AGF, de Jong G (2001) Random Regression Test-Day Model in The Netherlands. Interbull Bull 27, 155-158

De Roos APW, Harbers AGF, de Jong G (2004) Random Herd Curves in a Test-Day Model for Milk, Fat, and Protein Production of Dairy Cattle in The Netherlands. J Dairy Sci 87, 2693-2701

De Veer JC, Van Vleck LD (1987) Genetic Parameters for First Lactation Milk Yields at Three Levels of Herd Production. J Dairy Sci 70, 1434-1441

Druet T, Jaffrézic F, Boichard D, Ducrocq V (2003) Modeling Lactation Curves and Estimation of Genetic Parameters for First Lactation Test-Day Records of French Holstein Cows. J Dairy Sci 86, 2480-2490

Hammami H, Rekik B, Soyeurt H, Ben Gara A, Gengler N (2008) Genetic Parameters for Tunisian Holsteins Using a Test-Day Random Regression Model. J Dairy Sci 91, 2118-2126

Jakobsen JH, Madsen P, Jensen J, Pedersen J, Christensen LG, Sorensen DA (2002) Genetic Parameters for Milk Production and Persistency for Danish Holsteins Estimated in Random Regression Models using REML. J Dairy Sci 85, 1607-1616

Jamrozik J, Schaeffer LR (1997) Estimates of Genetic Parameters for a Test Day Model with Random Regressions for Yield Traits of First Lactation Holsteins. J Dairy Sci 80, 762-770

Jamrozik J, Schaeffer LR (2003) Genetic parameters for the Canadian Test Day Model with Legendre polynomials. Report to the Dairy Cattle Breeding and Genetics Committee and Genetic Evaluation Board, March 2003

Jensen J (2001) Genetic Evaluation of Dairy Cattle Using Test-Day Models. J Dairy Sci 84, 2803-2812

Kheirabadi KH, Alijani S, Rafat SA, Moghaddam GH (2012) [Use of Multi-trait Random Regression Test-Day model for Estimate of Genetic Parameters of Iranian Holsteins]. In: The 5th Iranian Congress on Animal Science, 29-30 August 2012, Isfahan University, Iran [In Persian]

Kirkpatrick M, Lofsvold D, Bulmer M (1990) Analysis of the Inheritance, Selection and Evolution of Growth Trajectories. Genetics 124, 979-993

Lidauer M, Mäntysaari EA (1999) Multiple Trait Reduced Rank Random Regression Test-Day Model for Production Traits. In: Proceedings Interbull Meeting, 1999, Zurich, Switzerland, Interbull Bull 22, 74-80 
Lidauer M, Mäntysaari EA, Strandén I (2003) Comparison of test-day models for genetic evaluation of production traits in dairy cattle. Livest Prod Sci 79, 73-86

López-Romero P, Carabaño MJ (2003) Comparing alternative random regression models to analyse first lactation daily milk yield data in Holstein-Friesian cattle. Livest Prod Sci 82, 81-96

Misztal I, Tsuruta S, Strabel T, Auvray B, Druet T, Lee DH (2002) BLUPF90 and related programs (BGF90). In: Proc 7th World Congr Genet Appl Livest Prod, Montpellier, France, CD-ROM communication 28:07

Muir BL, Kistemaker G, Jamrozik J, Canavesi F (2007) Genetic Parameters for a Multiple-Trait Multiple-Lactation Random Regression Test-Day Model in Italian Holsteins. J Dairy Sci 90, 1564-1574

Pool MH, Janss LLG, Meuwissen THE (2000) Genetic Parameters of Legendre Polynomials for First Parity Lactation Curves. J Dairy Sci 83, 2640-2649

Rekaya R, Carabaño MJ, Toro MA (1999) Use of test day yields for the genetic evaluation of production traits in Holstein-Friesian cattle. Livest Prod Sci 57, 203-217

Sahebhonar M, Moradi Shahrbabak M, Miraei Ashtiani SR, Sayad Nezhad MB (2010) [An Estimation of Genetic Trend for Production Traits and a Determination of the Impact of Some Factors on it in Iranian Holstein Cattle]. Iran J Anim Sci 41, 173-184. [in Persian]

Samoré AB, Boettcher PJ, Jamrozik J, Bagnato A, Groen AF (2002) Genetic parameters for production traits and somatic cell scores estimated with a multiple trait random regression model in Italian Holsteins. In: Proc 7th World Congr Genet Appl Livest Prod, Montpellier, France, 63-66

Schaeffer LR, Burnside EB (1976) Estimating the Shape of the Lactation Curve. Can J Anim Sci 56, 157-170

Strabel T, Jamrozik J (2006) Genetic Analysis of Milk Production Traits of Polish Black and White Cattle Using Large-Scale Random Regression Test-Day Models. J Dairy Sci 89, 3152-3163

Strabel T, Ptak E, Szyda J, Jamrozik J (2004) Multiple-Lactation Random Regression Test-Day Model for Polish Black and White Cattle. Interbull Bulletin 32, 133-136

Swalve HH (1995) Test day models in the analysis of dairy production data - a review. Arch Tierz 38, 591-612

Swalve HH, Guo Z (1999) An illustration of lactation curves stratified by lactation yields within herd. Arch Tierz $42,515-525$

Takma C, Akbas Y (2007) Estimates of genetic parameters for test day milk yields of a Holstein Friesian herd in Turkey with random regression models. Arch Tierz 50, 327-336

Tijani A, Wiggans GR, Van Tassell CP, Philpot JC, Gengler N (1999) Use of (Co)Variance Functions to Describe (Co)Variances for Test Day Yield. J Dairy Sci 82, 226.e1-226.e14

Van Der Werf JHJ, Goddard ME, Meyer K (1998) The Use of Covariance Functions and Random Regressions for Genetic Evaluation of Milk Production Based on Test Day Records. J Dairy Sci 81, 3300-3308

Yousefi-Golverdi A, Hafezian H, Chashnidel Y, Farhadi A (2012) Genetic parameters and trends of production traits in Iranian Holstein population. Afr J Biotechnol 11, 2429-2435

Zavadilová L, Jamrozik J, Schaeffer LR (2005) Genetic parameters for test-day model with random regressions for production traits of Czech Holstein cattle. Czech J Anim Sci 50, 142-154 